\title{
ANALISIS FAKTOR-FAKTOR YANG MEMPENGARUHI LOYALITAS PELANGGAN PADA NAEM 555 CUCIAN
}

\author{
Nor Asmi, Mardatillah \\ STIE Madani Balikpapan \\ Email: Marda.tillah95@stiemadani.ac.id
}

\begin{abstract}
This research aims to study and analyze the factors that influence customer loyalty at Naem 555 Laundry. This type of research is quantitative descriptive by using a sample of 103 people. The results of this study indicate that simultaneous variables of satisfaction, emotional bonding, trust, choice reduction and habit and history with company simultaneously have a significant effect to customer loyalty. Partially, satisfaction, trust, and choice reduction and habit variables have a significant effect on customer loyalty while the partial variables of emotional bonding and history with company are not significant to customer loyalty. The variable that has the most dominant influence on customer loyalty is the satisfaction variable.
\end{abstract}

Keywords: Satisfaction, Emotional Bonding, Trust, Choice Reduction and Habit, History with company, Customer Loyalty

\section{PENDAHULUAN}

Semakin padat dan dinamisnya kerja seseorang, menuntut masing masing pribadi untuk dapat mengatur waktu sebaik mungkin. Pada kenyataannya, sedikit sekali orang yang memiliki kemampuan manajerial dalam membagi waktunya, terutama hal yang dianggap sepele tetapi berpengaruh besar, seperti halnya mencuci pakaian. Pergeseran gaya hidup, pola pikir dan adanya tuntutan kebutuhan ekonomi menyebabkan masyarakat terutama yang berada di kota-kota besar, menjadi keluarga yang super sibuk dengan berbagai aktivitas kerjanya dan seringkali pekerjaaan mencuci menjadi urusan yang merepotkan dan banyak menyita waktu sehingga membutuhkan bantuan orang lain. Jika hal itu tidak dapat ditangani setiap harinya, pakaian akan menumpuk dan menjadi bau bahkan menjadi rusak.

Banyaknya bisnis cucian yang bermunculan dan kondisi persaingan yang semakin kompetitif seperti sekarang ini, membuat pemilik usaha cucian semakin menyadari betapa sentralnya peranan pelanggan dalam keberlangsungan bisnis yang mereka jalani, sehingga tetap dapat bertahan dalam persaingan bisnis yang ada dan konsumen tetap loyal dan tidak lari menggunakan penyedia jasa yang lain. Sebab apabila perusahaan memiliki seorang pelanggan yang loyal, maka hal itu dapat menjadi aset yang sangat bernilai bagi 
perusahaan, karena untuk mendapatkan pelanggan baru bukanlah hal yang mudah dan memerlukan waktu yang lama, maka sangatlah rugi bila melepas pelanggan yang telah loyal begitu saja.

Konsep loyalitas pelanggan itu sendiri, lebih banyak dikaitkan dengan perilaku (behavior) daripada dengan sikap. Untuk meneliti lebih jauh perihal loyalitas pelanggan maka penelitian terkaitpun dapat dilakukan, salah satunya dengan melakukan analisis faktor-faktor yang mempengaruhi loyalitas pelanggan. Menurut Zikmund (2003:72) dalam Chendy Ifca (2015) faktor-faktor yang mempengaruhi loyalitasadalah kepuasan (satisfaction), ikatan emosi (emotional bonding), kepercayaan (trust), kemudahan (choice reduction and habit) dan pengalaman dengan perusahaan (history waith company).

Naem 555 Cucian adalah salah satu usaha cucian kiloan di Balikpapan yang berlokasi di Jl. 21 Januari, Kelurahan Baru Tengah, Kecamatan Balikpapan Barat. Adapun jasa yang ditawarkan Naem 555 Cucian yaitu mencuci pakaian, pengeringan pakaian dan menyetrika pakaian. Bukan hanya pakaian Naem 555 juga menerima jasa mencuci bedcover, ambal dan tas. Konsumennya pun terbilang cukup banyak karena target pasar yang cukup luas seperti, mahasiswa, ibu rumah tangga, karyawan maupun pekerja yang memilki aktifitas yang cukup banyak sehingga tidak memiliki waktu untuk mencuci pakaian sendiri.

Dalam menjalankan usahanya pihak Naem 555 Cucian sering kali mendapatkan banyak komplain atau keluhan akan hasil akhir jasa yang disampaikan pelanggan, seperti pakaian kurang bersih atau kurang wangi, adanya kehilangan salah satu pakaian dari pelanggan, pakaian yang tertukar dan pakaian yang gosong karena disetrika. Adapun salah satu upaya Naem 555 Cucian dalam menangani komplain ataupun keluhan tersebut seperti, melakukan pencucian ulang untuk pakaian yang kurang bersih secara gratis, menyemprotkan ulang pewangi untuk pakaian yang kurang wangi. Untuk jenis keluhan pakaian hilang dan tertukar Naem 555 akan mencari pakaian yang hilang dan tertukar tersebut, kemudian berusaha bernegosiasi dengan pelanggan jika tidak ditemukan, serta akan mengganti $75 \%$ hingga $100 \%$ kerugian yang dialami pelanggan, dengan catatan pelanggan membawa nota cuciannya. Dan untuk pakaian yang gosong pihak Naem 555 akan mengganti 100\% kerugian yang dialami pelanggan.

Dengan adanya penanganan komplain dan keluhan dari setiap pelanggan, Naem 555 berharap bahwa pelanggan akan tetap loyal memakai jasa cucian di Naem 555 Cucian. 
Namun, berdasarkan data jumlah pelanggan Naem 555 Cucian dalam lima tahun terakhir ini cukup mengalami penurunan.

\section{Rumusan Masalah}

Berdasarkan latar belakang masalah di atas, masalah penelitian ini dapat dirumuskan sebagai berikut:

1. Apakah variabel kepuasan (satisfaction), ikatan emosi (emotional bonding), kepercayaan (trust), kemudahan (choice reduction and habit), pengalaman dengan perusahaan (history with company) secara simultan mempunyai pengaruh terhadap loyalitas pelanggan pada Naem 555 Cucian?

2. Apakah variabel kepuasan (satisfaction), ikatan emosi (emotional bonding), kepercayaan (trust), kemudahan (choice reduction and habit), pengalaman dengan perusahaan (history with company) secara parsial mempunyai pengaruh terhadap loyalitas pelanggan pada Naem 555 Cucian?

3. Variabel manakah diantara variabel kepuasan (satisfaction), ikatan emosi (emotional bonding), kepercayaan (trust), kemudahan (choice reduction and habit), pengalaman dengan perusahaan (history with company) yang mempunyai pengaruh dominan terhadap loyalitas pelanggan pada Naem 555 Cucian?

\section{Batasan Masalah}

Untuk memudahkan dan menghindari kesalahpahaman dalam penelitian ini dilakukan pembatasan masalah agar permasalahan yang dianalisa dapat terarah, sesuai tujuan dan sasaran yang diharapkan. Adapun batasan masalah dalam penelitian adalah :

1. Penelitian ini hanya berkaitan dengan variabel kepuasan (satisfaction), ikatan emosi (emotional bonding), kepercayaan (trust), kemudahan (choice reduction and habit), pengalaman dengan perusahaan (history with company) dalam mempengaruhi loyalitas pelangan pada Naem 555 Cucian

2. Penelitian ini dilakukan pada bulan Desember tahun 2018. 


\section{Kerangka Teori}

\section{Loyalitas pelanggan}

Kotler dan Keller (2009:138) mengungkapkan loyalitas adalah komitmen yang dipegang secara mendalam untuk membeli atau mendukung kembali produk atau jasa yang disukai di masa depan meski pengaruh situasi dan usaha pemasaran berpontesi menyebabkan pelanggan beralih.

Menurut Zikmund (2003:72) dalam Ifca Chendy (2015), mengemukakan aspek aspek yang mempengaruhi loyalitas pelanggan adalah :

\section{Kepuasan (Satisfaction)}

2. Ikatan emosi (Emotional bonding)

3. Kepercayaan (Trust)

4. Kemudahan (Choice reduction and habit).

5. Pengalaman dengan perusahaan (History with company).

Menurut Griffin (2005:31) loyalitas dapat didefinisikan berdasarkan perilaku pembeli. Pelanggan yang loyal adalah orang yang :

1.Melakukan pembelian berulang secara teratur

2. Membeli antarlini produk dan jasa

3. Merefrensikan kepada orang lain

4. Menunjukan kekebalan terhadap tarikan dari pesaing-pesaing

\section{Kepuasan (Satisfaction)}

Tjiptono (2015:45) menyatakan bahwa kepuasan pelanggan merupakan elemen produk dalam pemikiran dalam praktik pemasaran modern. Persaingan dapat dimenangkan apabila perusahaan mampu menciptakan dan mempertahankan pelanggan. Hassan (2008:58) mendefinisikan bahwa kepuasan pelanggan merupakan fungsi dasar dari sejumlah value produk (kinerja) yang dipersepsikan oleh pelanggan dibanding dengan harapan sebelum menggunakan.

Hassan (2014:68) mendefinisikan bahwa dalam pengukuran kepuasan konsumen, setidaknya ada dua aspek yang saling berkaitan, apa yang diukur serta metode dan skala pengukuran.

1. Variabel yang diukur 
a. Kepuasan pelanggan keseluruhan

b. Dimensi kepuasan pelanggan

c. Konfirmasi harapan

d. Minat pembelian ulang

e. Kesediaan untuk merekomendasikan

f. Ketidakpuasan Pelanggan

\section{Ikatan Emosional (Emotional Bonding)}

Zikmund (2003:72) dalam Ifca Chendy (2015) mendefinisikan Ikatan yang tercipta dari sebuah merek ialah ketika konsumen merasakan ikatan yang kuat dengan konsumen yang lain menggunakan produk atau jasa yang sama. Soutar Sweeney dalam Indriya Dwi Ratna (2008) mendefinisikan bahwa ikatan emosional konsumen terhadap merek yaitu berasal dari perasaan dan sikap positif dari pribadi seseorang secara keseluruhan.

Aron dan Westbay (1996) dalam Sukoco Badri dan Reza Aditya (2011) menyatakan bahwa keterikatan memiliki tingkatan yang tinggi bervariasi, dimana keterikatan yang tinggi diasosiasikan dengan perasaan yang kuat dari :

1. connection (koneksi)

2. affection (afeksi)

3. love (cinta)

4. passion (gairah)

\section{Kepercayaan (Trust)}

Abdurrahman (2015:434) mendefinisikan bahwa kepercayaan, yaitu keyakinan salah satu pihak yang dasarkan atas integritas pihak lain untuk memenuhi janjinya. Apabila perusahaan memenuhi komitmennya kepada pelanggan, kepercayaan akan tumbuh dan memperkuat kepercayaan pelanggan. Sementara Mowen dan Minor dalam Sangadji dan Sopiah (2013:201) mendefinisikan bahwa kepercayaan konsumen sebagai sebuah pengetahuan yang dimiliki oleh konsumen dan semua kesimpulan yang dibuat oleh konsumen tentang objek, atribut dan manfaatnya.

Mayer dkk dalam Jasfar (2009:169) menyatakan bahwa indikator kepercayaan terdiri dari 3 komponen, yaitu: 
a. Integritas (integrity)

b. Kebaikan (benevolence)

c. Kompetensi (competence)

\section{Kemudahan (Choice reduction and habit)}

Choice reduction and habit atau kemudahan menurut Zikmund (2003:72) dalam Ifca Chendy (2015) yaitu, seorang konsumen akan merasa nyaman jika dalam melakukan pembelian dia mendapatkan kemudahan. Kemudahan disini bisa berupa kemudahan dalam pencarian barang bisa juga kemudahan dalam melakukan transaksi. Keduanya memang hal harus diperhatikan oleh perusahaan, banyak perusahaan yang mengusung pembelian dan pembayaran melalui internet, hal ini diyakini oleh beberpa perusahaan dapat mempemudah konsumennya

Amijaya (2010) dalam Hardiawan Anandya (2013) menyatakan bahwa indikator kemudahan terdiri dari :

1. Efesiensi waktu

2. Kemampuan melakukan transaksi

3. Kemudahan operasional

4. Penggunaan yang fleksibel

\section{Pengalaman dengan Perusahaan (History with Company)}

Menurut Zikmund (2003:72) dalam Ifca Chendy (2015) pengalaman dengan perusahaan, yaitu sebuah pengalaman seseorang pada perusahaan dapat memebentuk perilaku. Pengalaman langsung oleh konsumen dalam mencoba dan mengevaluasi produk dapat mempengaruhi sikap konsumen terhadap produk. Ketika mendapatkan pelayanan yang baik dari perusahaan, maka kita akan mempunyai kesan baik terhadap perusahaan tesebut setelah pelanggan puas akan pelayanan dari perusahaan, mereka akan memperhitungkan untuk kembali membeli produk di masa yang akan datang.

Schmitt (1999) dalam Wulansari Dessy dan Yessy (2014) mengelompokkan customer experience kedalam 5 dimensi yang dapat digunakan untuk mengukur pengalaman konsumen yang terdiri dari :

1. Sense, yaitu indra yang dimiliki oleh manusia sebagai alat untuk merasakan produk dan jasa yang ditawarkan 
2. Feel, yaitu rasa yang ditampilkan melalui ide, kesenangan dan reputasi akan pelayanan konsumen

3. Think, yaitu pengalaman menuntut kecerdasan denagan tujuan menciptakan pengalaman kognitif dan pemecahan masalah dengan melibatkan konsumen secara kreatif

4. Act, yaitu didesain untuk menciptakan pengalaman konsumen yang berhubungan dengan tubuh atau fisik

5. Relate, yaitu adanya hubungan dengan orang lain, kelompok sosial lain (seperti pekerjaan, gaya hidup) atau identitas sosial yang lebih luas

\section{Penelitian Terdahulu}

Penelitian pertama, oleh Chendy Ifca pada tahun 2015 dari Fakultas Ilmu sosial dan Politik Universitas Riau yang berjudul "Faktor Faktor Yang Mempengaruhi Loyalitas Pelanggan Garudamiles Pada Maskapai Penerbangan Garuda Indonesia Airways Di Pekanbaru”. Berdasarkan hasil penelitian ini, respon responden setuju dengan faktor-faktor yang mempengaruhi loyalitas pelanggan dan responnya sangat setuju dan loyalitas, dan faktor dominannya adalah kepuasan.

Penelitian kedua, oleh Triza Articia Gennie pada tahun 2019 dari Universitas Riau yang berjudul "Faktor-Faktor yang mempengaruhi Loyalitas Pelanggan di Hotel Travelodge Batam". Berdasarkan teori Zikmund (2007: 72) tentang faktor-faktor yang mempengaruhi loyalitas pelanggan yang terdiri dari lima indikator terbukti mampu mempengaruhi loyalitas pelanggan di Hotel Travelodge Batam sebesar 80,1\%. Sedangkan sisanya sebesar 19,9\% dipengaruhi atau dijelaskan oleh variabel lain yang tidak dimasukkan dalam model penelitian ini. Dari lima faktor yang mempengaruhi loyalitas pelanggan di Hotel Travelodge Batam, yang paling dominan mempengaruhi adalah faktor satisfaction yaitu berpengaruh sebesar $77,8 \%$.

Penelitian ketiga, oleh Sasha Dwi Harumi pada tahun 2016 yang berjudul "Pengaruh Kepercayaan dan Kepuasan Pelanggan Terhadap Loyalitas Pelanggan di Perusahaan Seiko Laundry Medan”. Berdasarkan hasil analisis didapatkan koefisien determinasi antara X1 dan X2 dengan $Y$ sebesar $R 2=0,053$ dengan $\mathrm{p}=0,034<0,05$. Nilai tersebut menunjukkan bahwa secara bersama-sama terdapat pengaruh yang signifikan antara kepercayaan dan kepuasan pelanggan terhadap loyalitas pelanggan. 
Penelitian keempat, oleh Suherti tahun 2016 dari Fakultas Ekologi Manusia, Institut Pertanian Bogor yang berjudul "Pengaruh Kepuasan Terhadap Loyalitas Konsumen Laundry Kiloan Di Dramaga Bogor”. Hasil penelitian menunjukkan bahwa tingkat kepuasan secara keseluruhan berada pada kategori "puas", sedangkan tingkat loyalitas berada pada kategori “cukup loyal”.

Penelitian kelima, oleh Rendy Alfasha tahun 2018 dari Universitas Katolik Parahyangan yang berjudul "Analisis Pengaruh Kualitas Pelayanan Terhadap Loyalitas Pelanggan Topklin Laundry”. Hasil penelitian ini menunjukkan kepuasan responden terhadap variabel pelayanan (reability, responsiveness, assurance, empathy, tangibles) sudah cukup baik namun ada beberapa hal yang perlu ditingkatkan. Hasil regresi berganda untuk model ini, menunjukan variabel responsiveness tidak berpengaruh secara signifikan terhadap loyalitas pelanggan. Namu variabel reability, assurance, empathy, dan tangibles berpengaruh secara signifikan terhadap loyalitas pelanggan.

\section{Hipotesis}

1. $\mathrm{H}_{1}$ : Diduga variabel kepuasan (satisfaction), ikatan emosi (emotional bonding), kepercayaan (trust), kemudahan (choice reduction and habit), pengalaman dengan perusahaan (history with company) secara simultan berpengaruh signifikan terhadap loyalitas pelanggan pada Naem 555 Cucian

2. $\mathrm{H}_{2}$ : Diduga variabel kepuasan (satisfaction), ikatan emosi (emotional bonding), kepercayaan (trust), kemudahan (choice reduction and habit), pengalaman dengan perusahaan (history with company) secara parsial berpengaruh signifikan terhadap loyalitas pelanggan pada Naem 555 Cucian

3. H3 : Diduga variabel kepuasan (satisfaction) berpengaruh dominan terhadap loyalitas pelanggan pada Naem 555 Cucian

\section{METODE PENELITIAN}

\section{Jenis Penelitian}

Dalam penelitian ini peneliti menggunakan metode kuantitatif deskriptif. Metode penelitian kuantitatif dapat diartikan sebagai metode penelitian yang berlandaskan pada filsafat positivisme, digunakan untuk meneliti pada populasi atau sampel tertentu, 
pengumpulan data menggunkan instrumen penelitian, analisis data bersifat kuantitatif detatif / statistik dengan tujuan untuk menguji hipotesis yang telah ditetapkan (Sugiyono, 2016:8).

\section{Data Penelitian}

\section{Sumber Data}

Data yang diperoleh dalam penelitian ini adalah data primer. Data primer merupakan data yang didapat dari sumber pertama baik dari individu atau perorangan seperti hasil dari wawancara maupun hasil pengisian kuesioner yang dibagikan dan diisi oleh para responden, yang dilakukan oleh peneliti (Umar, 2013:42). Data primer dalam penelitian ini diperoleh melalui kuesioner yang dibagikan kepada para pelanggan Naem 555 Cucian.

\section{Teknik Pengumpulan data}

Teknik pengumpulan data yang digunakan dalam penelitian ini adalah angket (kuesioner). Teknik angket (kuesioner) merupakan suatu pengumpulan data dengan memberikan atau menyebarkan pertanyaan kepada responden dengan harapan memberikan respons atas daftar pertanyaan tersebut.

\section{Populasi dan Sampel}

Populasi adalah wilayah generalisasi yang terdiri atas obyek subyek yang mempunyai kualitas dan karakteristik tertentu yang ditetapkan oleh peneliti untuk dipelajari kemudian ditarik kesimpulannya(Sugiyono,2016:80). Dalam penelitian ini yang menjadi populasi adalah pelanggan Naem 555 Cucian berdasarkan data pelanggan di tahun 2018 yang berjumlah 930 pelanggan.

Sampel adalah bagian dari jumlah dan karakteristik yang dimiliki oleh populasi (Sugiyono,2016:62). Teknik pengambilan sampel yang digunakan adalah nonprobability sampling artinya, adalah teknik pengambilan sampel yang tidak memberi peluang atau kesempatan sama bagi setiap unsur atau anggota populasi untuk dipilih menjadi sampel (Sugiyono,2015:154). Metode yang diambil dari nonprobability sampling adalah purposive sampling. Purposive sampling adalah pengambilan sampel berdasarkan pertimbangan tertentu dari peneliti sehingga sampel hanya representatif untuk populasi yang diteliti (Arifin,2017:10). 
Alasan peneliti menentukan jumlah sampel berdasarkan teori di atas adalah sebagai beikut :

1. Dari populasi yang ada peneliti hanya akan mengambil sampel pada bulan Desember tahun 2018 yang berjumlah 103 pelanggan

2. Kendala sumber daya, keterbatasan waktu, dana dan juga sumber daya manusia yang membatasi besarnya sampel.

3. Dijabarkan bahwa ukuran sampel yang layak digunakan dalam penelitian adalah antara 30 sampai dengan 500 .

\section{Metode Analisis}

\section{Analisis Deskriptif}

Analisis deskriptif (descriptive) digunakan untuk penggambaran tentang statistik data seperti min, max, mean, sum, standar deviasi, variance, range dan lain-lain dan untuk mengukur distribusi data dengan skewness dan kurtosis (Priyatno, 2014:30). Pengujian statistik deskriptif digunakan untuk menghitung jumlah frekuensi untuk data profil responden dan data jawaban hasil responden.

\section{Pengujian Validitas dan Reliabilitas}

\section{Uji Validitas}

Menurut Sugiyono (2015:361) validitas merupakan derajat ketepatan antara data yang terjadi pada objek penelitian dengan data yang dapat dilaporkan oleh peneliti.pengujian signifikansi dilakukan dengan kriteria $\mathrm{r}$ tabel pada tingkat signifikansi 0,05 dengan uji 2 sisi. Jika nilai positif dan $\mathrm{r}$ hitung $\geq \mathrm{r}$ tabel, maka item dapat dinyatakan valid (demikian pula sebaliknya) (Priyatno, 2012:117).

\section{Uji Reliabilitas}

Menurut Ghozali (2013:47) reliabilitas adalah alat untuk mengukur suatu kuesioner yang merupakan indikator dari variabel. Suatu kuesioner dikatakan reliabel atau handal jika jawaban seseorang terhadap pertanyaan adalah konsisten atau stabil dari waktu ke waktu. Jika nilai Alpha > 0,60 maka reliabel. Metode yang sering digunakan dalam penelitian untuk mengukur skala rentangan (seperti skala Likert 1-5) adalah Cronbach Alpha (Priyatno, 2012:120) 


\section{Uji Asumsi Klasik}

\section{Uji Normalitas}

Uji normalitas untuk mengetahui apakah variabel dependen, independen atau keduanya berdistribusi normal, mendekati normal atau tidak. Mendeteksi apakah data berdistribusi normal atau tidak dapat diketahui dengan menggambarkan penyebaran data melalui sebuah grafik normal P-P plot of regression standardized residual. Jika data menyebar disekitar garis diagonal dan mengikuti arah garis diagonalnya, model regresi memenuhi asumsi normalitas (Husein, 2013:181). Sedangkan menurut Sujarweni (2015:52) normalitas data juga dapat dilihat denngan menggunakan uji normal Kolmogorov-Smirnov. Dengan mengambil keputusan sebagai berikut:

a. Jika sig > 0,05 maka data berdistribusi normal.

b. Jika sig $<0,05$ maka data tidak berdistribusi normal.

\section{Uji Multikolinieritas}

Uji multikolinieritas bertujuan untuk menguji apakah model regresi ditemukan adanya kolerasi antara variabel bebas (independen). Adanya multikolinieritas pada model regresi dapat dilihat dari torelance value $>$ 0,10 atau nilai variance inflation factor (VIF) < 10 (Ghozali, 2013:106).

\section{Uji Heteroskedastisitas}

Uji heteroskedastisitas bertujuan menguji apakah dalam model regresi terjadi ketidaksamaan variance dari residual satu pengamatan ke pengamatan lain. Model regresi yang baik adalah yang homoskedastisitas atau tidak terjadi heteroskedastisitas (Ghozali, 2013:139). Cara mengetahui ada tidaknya heteroskedastisitas pada suatu model dapat dilihat dengan pola gambaran Scatterplot (Sujarweni, 2015:186). Regresi yang tidak terjadi heteroskedastisitas jika:

\section{Uji Autokorelasi}

Uji autokorelasi dilakukan untuk mengetahui apakah dalam sebuah model regresi linier terdapat hubungan yang kuat baik positif maupun negatif antar data yang ada pada variabel-variabel penelitian (Umar, 2013:182). Model regresi yang baik seharusnya tidak 
terjadi autokorelasi. Metode pengujian menggunakan uji Durbin-Watson (DW test). Pengambilan keputusan pada uji Durban Watson sebagai berikut (Priyatno, 2013:106 ):

a. DU < DW < 4-DU maka Ho diterima, artinya tidak terjadi autokorelasi.

b. DU < DL atau DW > 4-DL maka Ho ditolak, artinya terjadi autokorelasi.

c. DL $<$ DW $<$ DU atau 4-DU < 4-DL, artinya tidak ada kepastian atau kesimpulan yang pa

\section{Analisis Regresi Linier Berganda}

Regresi yang memiliki satu variabel dependen dan lebih dari satu variabel independen (Sujarweni, 2015:149). Model persamaan regresi linier sebagai berikut:

$\mathrm{Y}=\mathrm{a}+\mathrm{b} 1 \mathrm{X} 1+\mathrm{b} 2 \mathrm{X} 2+\mathrm{b} 3 \mathrm{X} 3+\mathrm{b} 4 \mathrm{X} 4+\mathrm{b} 5 \mathrm{X} 5+\mathrm{e}$

Keterangan:

$\mathrm{Y}=$ variabel loyalitas pelanggan

$\mathrm{a}=$ konstanta

$\mathrm{b}=$ koefisien regresi dari setiap variabel $\mathrm{X}$

$\mathrm{X}_{1}=$ variabel kepuasan

$\mathrm{X}_{2}=$ variabel ikatan emosi

$\mathrm{X}_{3}=$ variabel kepercayaan

$\mathrm{X}_{4}=$ variabel kemudahan

$\mathrm{X}_{5}=$ variable pengalaman dengan perusahaan

$\mathrm{e}=$ standard error

\section{Koefisien Korelasi (R)}

Uji koefisien korelasi digunakan untuk mengetahui hubungan antara dua atau lebih variabel bebas terhadap variabel terikat secara serentak. Adapun pedoman untuk memberikan interpretasi koefisien korelasi seperti yang dijelaskan oleh Sujarweni (2015:127) adalah sebagai berikut: 
a. 0,00 sampai 0,20 berarti korelasi sangat lemah.

b.0,21 sampai 0,40 berarti korelasi lemah.

c.0,41 sampai 0,70 berarti korelasi kuat.

d. 0,71 sampai 0,90 berarti korelasi sangat kuat.

e. 0,91 sampai 0,99 berarti korelasi kuat sekali.

f. 1 berarti korelasi sempurna

\section{Koefisien Determinasi $\left(\mathbf{R}^{2}\right)$}

Menurut Ghozali (2016:95) koefisien determinasi $\left(\mathrm{R}^{2}\right)$ yaitu mengukur seberapa jauh kemampuan model dalam menerangkan variasi variabel dependen. Nilai koefisien determinasi adalah antara nol dan satu. Nilai $\mathrm{R}^{2}$ yang kecil berarti kemampuan variabelvariabel bebas dalam menjelaskan variabel terkait amat terbatas. Begitu pula sebaliknya, nilai semua informasi satu berarti variabel-variabel bebas (independen) memberikan hampir semua informasi yang dibutuhkan untuk memprediksi variasi variabel terikat (dependen).

\section{Pengujian Hipotesis}

\section{Uji F (Uji Simultan)}

Uji F digunakan untuk mengetahui apakah variabel independen secara bersama-sama atau simultan mempengaruhi variabel dependen (Ghozali, 2013:177). Uji F ini membandingkan nilai $F_{\text {hitung }}$ dengan nilai $F_{\text {tabel }}$ pada tingkat keyakinan tertentu untuk melihat tingkat signnifikan pengaruh variabel bebas terhadap variabel terikat secara bersama-sama. Penentuan uji F dapat dilakukan dengan tahapan sebagai berikut :

1. Merumuskan hipotesis

Ho = Secara simultan tidak ada pengaruh signifikan antara variabel kepuasan, ikatan emosi, kepercayaan, kemudahan, pengalaman dengan perusahaan terhadap loyalitas pelanggan pada Naem 555 Cucian

$\mathrm{Ha}=$ Secara simultan ada pengaruh signifikan antara variabel kepuasan, ikatan emosi, kepercayaan, kemudahan, pengalaman dengan perusahaan terhadap loyalitas pelanggan pada Naem 555 Cucian

2. Menentukan tingkat signifikansi 
Tingkat signifikansi menggunakan $\alpha=5 \%(0,05)$.

3. Menentukan Fhitung

Perhitungan menggunakan bantuan program SPSS versi 20.

4. Menentukan $\mathrm{F}_{\text {tabel }}$

Berdasarkan daftar tabel $\mathrm{F}$ dengan tingkat signifikan $\mathrm{F}_{0,05}$.

5. Kriteria pengujian :

$\mathrm{H}_{\mathrm{o}}$ diterima apabila $\mathrm{F}_{\text {hitung }}<\mathrm{F}_{\text {table }}$

$\mathrm{H}_{\mathrm{o}}$ ditolak apabila $\mathrm{F}_{\text {hitung }}>\mathrm{F}_{\text {table }}$

\section{Uji t (Uji Parsial)}

Uji parsial digunakan untuk mengetahui pengaruh masing-masing variabel independen terhadap variabel dependen (Ghozali, 2013:178). Dalam melakukan uji t, digunakan penyusun hipotesis yang akan diuji.

1. Merumuskan hipotesis

$\mathrm{H}_{0}=$ Secara parsial tidak ada pengaruh signifikan antara variabel kepuasan, ikatan emosi,

kepercayaan, kemudahan, pengalaman dengan perusahaan terhadap loyalitas pelanggan pada Naem 555 Cucian

$\mathrm{Ha}=$ Secara parsial tidak ada pengaruh signifikan antara variabel kepuasan, ikatan emosi, kepercayaan, kemudahan, pengalaman dengan perusahaan terhadap loyalitas pelanggan pada Naem 555 Cucian

2. Menentukan tingkat signifikansi

Tingkat signifikansi menggunakan $\alpha=5 \%(0,05)$.

3. Menentukan $t$ hitung

Perhitungan menggunakan bantuan program SPSS versi 21.

4. Menentukan $t_{\text {tabel }}$

Berdasarkan daftar tabel $\mathrm{t}$ dengan tingkat signifikansi $\mathrm{t}_{0,05}$, dengan menggunakan uji 2 arah yang diperoleh dari $0,05 / 2=0,025$. Dimana derajat kebebasan (df) adalah n-k-1 (n adalah jumlah data dan $\mathrm{k}$ adalah jumlah variabel independen). 
5. Kriteria pengujian :

$\mathrm{H}_{0}$ diterima apabila $\mathrm{t}_{\text {hitung }}<\mathrm{t}_{\text {tabel }}$

$\mathrm{H}_{0}$ ditolak apabila $\mathrm{t}_{\text {hitung }}>\mathrm{t}_{\text {tabel }}$

\section{HASIL PENELITIANDAN PEMBAHASAN}

\section{Uji Validitas}

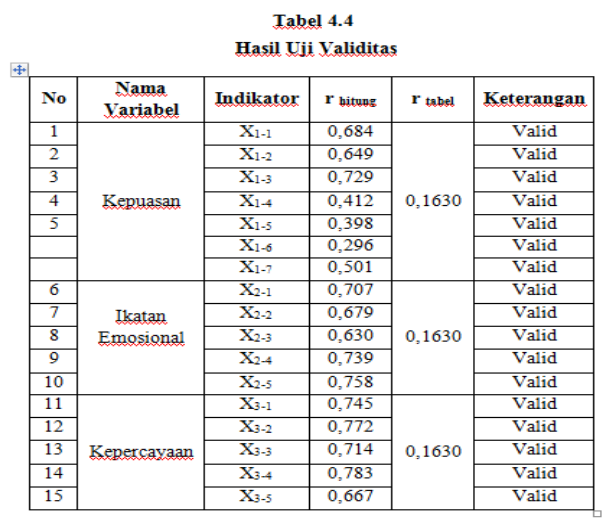

\begin{tabular}{|c|c|c|c|c|c|}
\hline 16 & \multirow{5}{*}{ Kemudahaan } & $\mathrm{X}_{4-1}$ & 0,799 & \multirow{5}{*}{0,1630} & Valid \\
\hline 17 & & $\mathrm{X}_{4-2}$ & 0,809 & & Valid \\
\hline 18 & & $\mathrm{X}_{4-3}$ & 0,843 & & Valid \\
\hline 19 & & $\mathrm{X}_{44}$ & 0,581 & & Valid \\
\hline 20 & & $\mathrm{X}_{4-5}$ & 0,630 & & Valid \\
\hline 21 & \multirow{5}{*}{$\begin{array}{c}\text { Pengalaman } \\
\text { dengan } \\
\text { perusahaan }\end{array}$} & $\mathrm{X}_{5-1}$ & 0,662 & \multirow{5}{*}{0,1630} & Valid \\
\hline 22 & & $\mathrm{X}_{5-2}$ & 0,647 & & Valid \\
\hline 23 & & $\mathrm{X}_{5-3}$ & 0,574 & & Valid \\
\hline 24 & & $\mathrm{X}_{5-4}$ & 0,679 & & Valid \\
\hline 25 & & $\mathrm{X}_{5.5}$ & 0,697 & & Valid \\
\hline 26 & \multirow{5}{*}{$\begin{array}{l}\text { Loyalitas } \\
\text { Pelanggan }\end{array}$} & $\mathrm{Y}_{1}$ & 0,766 & \multirow{5}{*}{0,1630} & Valid \\
\hline 27 & & $\mathrm{Y}_{.2}$ & 0,730 & & Valid \\
\hline 28 & & $\mathrm{Y}_{.3}$ & 0,692 & & Valid \\
\hline 29 & & $\mathrm{Y} .4$ & 0,542 & & Valid \\
\hline 30 & & $\mathrm{Y} .5$ & 0,554 & & Valid \\
\hline
\end{tabular}

Dari hasil tabel di atas dapat dinyatakan bahwa semua ítem dalam kuesioner dinyatakan valid karena $r$ hitung $>r$ table

\section{Uji Reliabelitas}

Tabel 4.5

Hasil Uji Reliabilitas

\begin{tabular}{|c|c|c|}
\hline Variabel & $\begin{array}{c}\text { Cronbach } \\
\text { Alpha }\end{array}$ & Keterangan \\
\hline Kepuasan (X1) & 0,558 & Tidak Reliabel \\
\hline Ikatan Emosional (X2) & 0,742 & Reliabel \\
\hline Kepercayaan (X3) & 0,790 & Reliabel \\
\hline Kemudahan (X4) & 0,790 & Reliabel \\
\hline $\begin{array}{c}\text { Pengalaman dengan } \\
\text { perusahaan (X5) }\end{array}$ & 0,659 & Reliabel \\
\hline Loyalitas Pelanggan (Y) & 0,692 & Reliabel \\
\hline Sumber: Hasil Olah Uji SPSS 20 & \\
\hline
\end{tabular}


Berdasarkan tabel diatas variabel kepuasan (X1) tidak reliable. Hasil uji reliabilitas diperoleh nilai Cronbach Alpha setiap variabel penelitian > 0,6.

\section{Uji Asumsi Klasik}

\section{Hasil Uji Normalitas}

Berdasarkan hasil uji normalitas menggunakan program SPSS 20, diperoleh hasil grafik dimana data mendekati garis diagonal. Dengan demikian, model regresi memenuhi asumsi normalitas.Selain dengan grafik, pengujian normalitas juga dapat dilakukan dengan uji statistik yaitu dengan non-parametrik Kolmogorov-Smirnov (K-S). Data dikatakan berdistribusi normal apabila nilai signifikan di atas 0,05 .

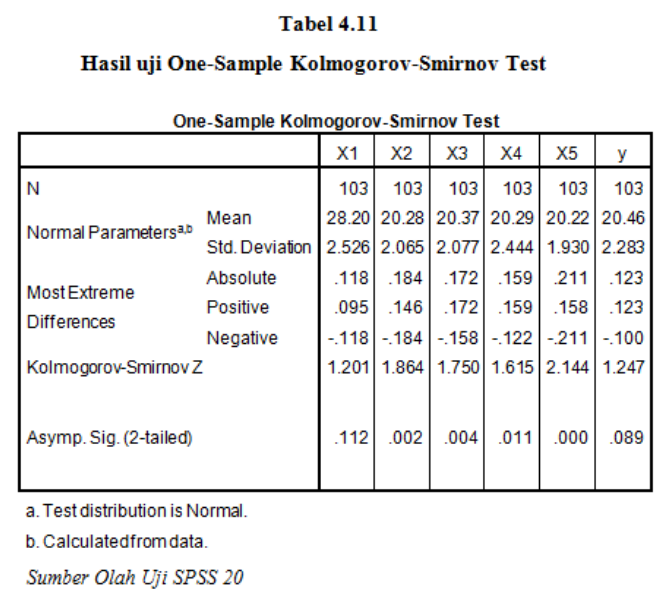

a. $\mathrm{X}_{1}$ (Variabel kepuasan) 0,112 > 0,05 maka Ho diterima dan Ha ditolak berarti data residual berdistribusi normal.

b. $\mathrm{X}_{2}$ (Variabel ikatan emosional) $0,002<0,05$ maka Ho dittolak dan Ha diterima

c. berarti data residual tidak berdistribusi normal.

d. $\mathrm{X}_{3}$ (Variabel kepercayaan) $0,004<0,05$ maka Ho ditolak dan Ha diterima berarti data residual tidak berdistribusi normal.

e. $\mathrm{X}_{4}$ (Variabel kemudahan) 0,011 >0,05 maka Ho diterima dan Ha ditolak berarti data residual berdistribusi normal.

f. $\mathrm{X}_{5}$ (Variabel pengalaman dengan perusahaan) $0,000<0,05$ maka Ho ditolak dan Ha diterima berarti data residual tidak berdistribusi normal.

g. Y (Variabel loyalitas pelanggan) 0,089 > maka Ho diterima dan Ha ditolak berarti data residual berdistribusi normal 


\section{Hasil Uji Multikolinieritas}

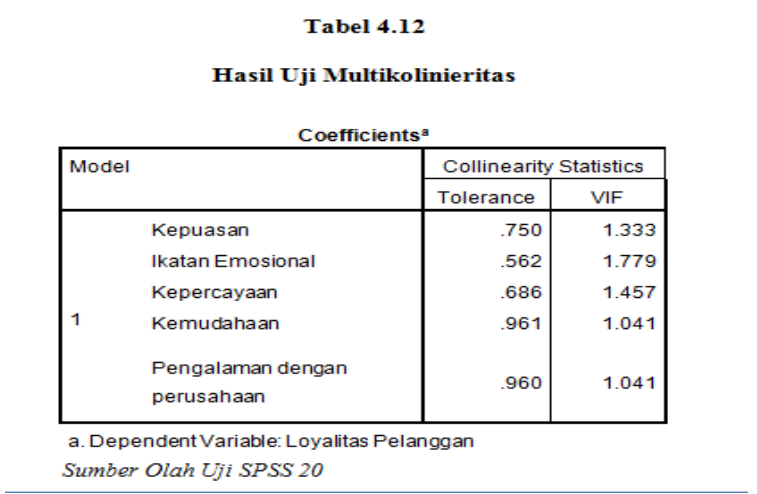

Hasil uji multikolinieritas didapatkan hasil nilai tolerance variabel bebas $>0,1$ dan nilai VIF < 10 Maka dapat disimpulkan bahwa tidak terdapat multikoliniertias pada model regresi.

\section{Uji Heteroskedastisitas}

Gejala heteroskedastisitas dapat dideteksi dengan melihat grafik scatterplot antara nilai prediksi variabel terikat (dependen) yaitu ZPRED dengan residualnya SRESID.

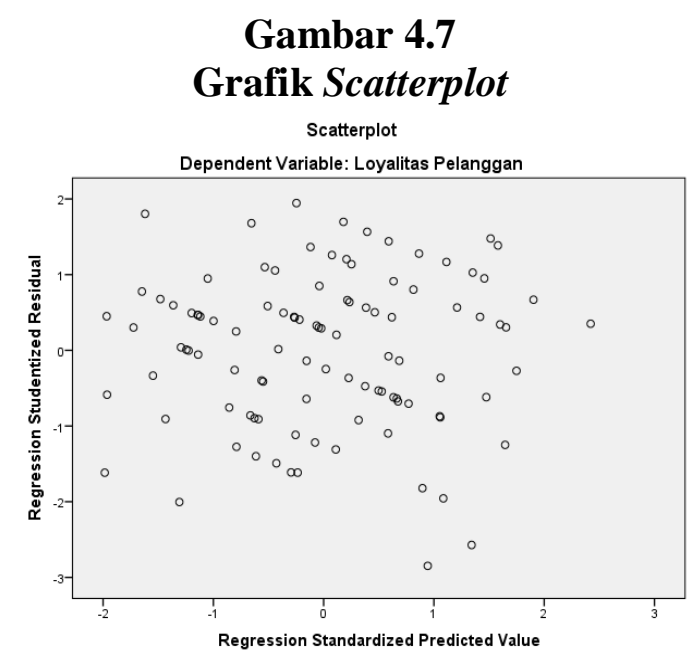

Sumber: Hasil Olah Uji SPSS 20

Pada gambar 4.7 terlihat tidak ada pola yang jelas, serta titik-titik menyebar di atas dan di bawah angka 0 pada sumbu $\mathrm{Y}$ dapat disimpulkan bahwa tidak terjadi heteroskedastisitas. Namun pengujian sebaiknya menggunakan 2 metode sehingga akan didapat hasil yang lebih baik. Untuk mengukur heteroskedastisitas dapat juga diketahui dengan 
menggunakan uji Glejser, yaitu uji yang digunakan dengan cara meregresikan antara variabel independen $(\mathrm{X})$ dengan nilai absolute residualnya. Jika nilai signifikansinya lebih dari 0,05 maka tidak terjadiheteroskedastisitas (Priyatno,2014:115).

Tabel 4.13

Hasil Uji Glejser

\begin{tabular}{|c|c|c|c|c|c|c|}
\hline \multicolumn{7}{|c|}{ Coefficients $^{\mathrm{a}}$} \\
\hline \multirow[t]{2}{*}{ Mod } & & \multicolumn{2}{|c|}{$\begin{array}{l}\text { Unstandardized } \\
\text { Coefficients }\end{array}$} & \multirow{2}{*}{$\begin{array}{c}\text { Standardiz } \\
\text { ed } \\
\text { Coefficient } \\
\text { s } \\
\text { Beta }\end{array}$} & \multirow[t]{2}{*}{$t$} & \multirow[t]{2}{*}{ Sig. } \\
\hline & & $B$ & Std. Error & & & \\
\hline \multirow{6}{*}{1} & (Constant) & 15.685 & 3.429 & & 4.574 & .000 \\
\hline & Kepuasan & .419 & .091 & .463 & 4.625 & .000 \\
\hline & Ikatan Emosional & -.077 & .128 & -.069 & -.599 & .551 \\
\hline & Kepercayaan & -.333 & .115 & -303 & -2.890 & .005 \\
\hline & Kemudahaan & .172 & .083 & .184 & 2.081 & .040 \\
\hline & $\begin{array}{l}\text { Pengalaman } \\
\text { dengan perusahaan }\end{array}$ & -.109 & .105 & -.092 & -1.038 & .302 \\
\hline
\end{tabular}

a. Dependent Variable: Loyalitas Pelanggan

Berdasarkan tabel coefficients dalam uji glejser, maka dengan melihat nilai sign, dapat disimpulkan :

1. $\mathrm{X}_{1}$ (kepuasan) $0,000<0,05$ (level of significance).. Berarti terjadi heteroskedastisitas.

2. $\mathrm{X}_{2}$ (ikatan emosional) $0,551>0.05$ (level of significance). Berarti tidak terjadi heteroskedastisitas.

3. $\mathrm{X}_{3}$ (kepercayaan) $0,005<0,05$ (level of significance). Berarti terjadi heteroskedastisitas.

4. $\mathrm{X}_{4}$ (kemudahan) $0,040>0,005$ (level of significance). Berarti terjadi heteroskedastisitas.

5. $\mathrm{X}_{5}$ (pengalaman dengan perusahaan) 0,302 $>0,005$ (level of significance). Berarti tidak terjadi heteroskedastisitas.

\section{Uji Autokorelasi}


Tabel 4.14

Hasil Uji Durbin-Watson

\begin{tabular}{|l|l|r|r|r|r|}
\multicolumn{7}{|c|}{ Model Summary } \\
\hline Model & \multicolumn{1}{|c|}{$R$} & R Square & $\begin{array}{c}\text { Adjusted R } \\
\text { Square }\end{array}$ & $\begin{array}{c}\text { Std. Error of the } \\
\text { Estimate }\end{array}$ & Durbin-Watson \\
\hline 1 & $.519^{\mathrm{a}}$ & .269 & .232 & 2.001 & 1.818 \\
\hline
\end{tabular}

a. Predictors: (Constant), Pengalaman dengan perusahaan, Kepercayaan, Kemudahaan,

Kepuasan, Ikatan Emosional

b. Dependent Variable: Loyalitas Pelanggan

Hasil output didapatkan nilai DW sebesar 1,818 selanjutnya nilai ini akan dibandingkan dengan nilai tabel signifikansi 5\%, dengan $\mathrm{n}=101$ dan $\mathrm{k}=5$ didapat nilai DU 1,7809 dan nilai DL 1,5736. Dengan menggunakan rumus DU $<$ DW $<4$-DU atau 1,7809 $<1,818<2,2191$ sehingga dapat disimpulkan Ho diterima, artinya tidak terjadi autokorelasi.

\section{Uji Analisis Regresi Linier Berganda}

Berdasarkan hasil uji analisis linear berganda dapat disimpulkan sebuah persamaan regresi linier berganda sebagai berikut:

$Y=15,685+0,419 X_{1}+(0,077) X_{2}+(0,333) X_{3}+0,172 X_{4}+(0,109) X_{5}$

\section{Hasil Uji Koefisien Korelasi (R)}

Tabel 4.16
$\begin{aligned} & \text { Hasil Uji Koefisien Korelasi (R) } \\
& \text { Model Summary }\end{aligned}$
\begin{tabular}{|l|r|r|r|r|}
\hline Model & R & R Square & $\begin{array}{c}\text { Adjusted R } \\
\text { Square }\end{array}$ & Std. Error of the Estimate \\
\hline 1 & $.519^{3}$ & .269 & .232 & \\
\hline
\end{tabular}
a. Predictors: (Constant), Pengalaman dengan perusahaan, Kepercayaan,
Kemudahaan, Kepuasan, Ikatan Emosional
b. Dependent Variable: Loyalitas Pelanggan
Sumber: Hasil Olah Uji SPSS 20

Berdasarkan tabel 4.16 Menunjukkan bahwa nilai koefisien korelasi (R) sebesar 0,519. Apabila dilihat dari nilai interval koefisien korelasi berada di level 0,40 sampai 0,599 berarti korelasi sedang.

\section{Koefisien Determinasi $\left(\mathbf{R}^{2}\right)$}




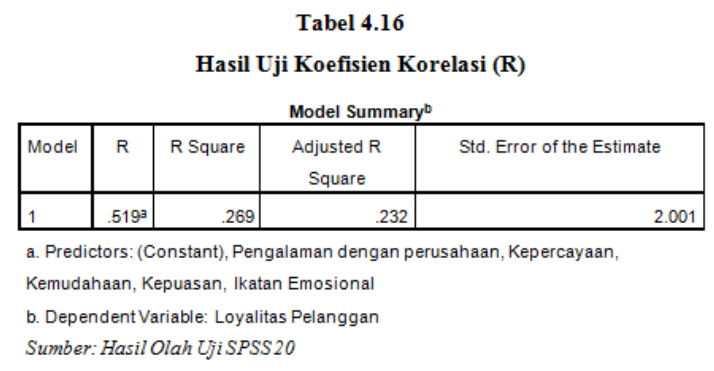

Berdasarkan tabel 4.17 nilai koefisien determinasi $\left(\mathrm{R}^{2}\right)$ ditunjukkan oleh nilai Adjusted R Square sebesar 0,269. Hal ini berarti variabel kepuasan $\left(\mathrm{X}_{1}\right)$, ikatan emosional $\left(\mathrm{X}_{2}\right)$, kepercayaan $\left(\mathrm{X}_{3}\right)$ kemudahan $\left(\mathrm{X}_{4}\right)$ dan pengalaman dengan perusahaan $\left(\mathrm{X}_{5}\right)$ memberikan sumbangan pengaruh sebesar $26,9 \%$ terdapat variabel dependen, sedangkan sisanya sebesar 73,1\% dipengaruhi atau dijelaskan oleh variabel lain yang tidak diajukan dalam penelitian ini.

\section{Uji Simultan (Uji F)}

Tabel 4.18

Hasil Uji Secara Simultan (F)

\begin{tabular}{|l|r|r|r|l|l|}
\hline Model & Sum of Squares & \multicolumn{1}{c|}{ df } & Mean Square & F & Sig. \\
\hline Regression & 143.111 & 5 & 28.622 & 7.147 & $.000^{\circ}$ \\
Residual & 388.443 & 97 & 4.005 & & \\
Total & 531.553 & 102 & & & \\
\hline
\end{tabular}

a. Dependent Variable: Loyalitas Pelanggan

b. Predictors: (Constant), Pengalaman dengan perusahaan, Kepercayaan,

Kemudahaan, Kepuasan, Ikatan Emosional

Sumber: Hasil Olah Uji SPSS 20

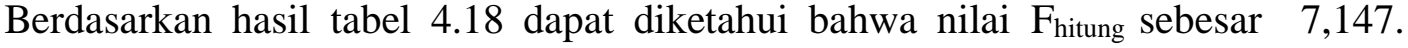
Selanjutnya untuk mengetahui nilai $\mathrm{F}_{\text {tabel }}$ digunakan tabel statistik dengan nilai signifikan $5 \%$ atau 0,05. Dengan memasukkan rumus $\mathrm{df}_{1}$ dan $\mathrm{df}_{2}$ maka perhitungan untuk $\mathrm{F}_{\text {tebel }}$ adalah sebagai berikut:

$$
\begin{aligned}
\mathrm{F}_{\text {tabel }} & =\alpha ;(\mathrm{k}-1) ;(\mathrm{n}-\mathrm{k}-1) \\
& =0,05 ;(6-1) ;(103-5-1) \\
& =0,05 ; 5 ; 97
\end{aligned}
$$

Dengan hasil perhitungan di atas, apabila dilihat pada tabel distribusi $\mathrm{F}$ diketahui bahwa nilai $F_{\text {tabel }}$ adalah sebesar 2,31. Jika dibandingkan dengan nilai $F_{\text {hitung }}$ yang telah diperoleh sebelumnya yaitu sebesar 7,147 maka akan terlihat bahwa nilai $F_{\text {hitung }}$ lebih besar dari nilai $\mathrm{F}_{\text {tabel }}$ dan nilai signifikan yang diperoleh sebesar 0,000 lebih kecil dari 0,05.

\section{Uji Parsial (Uji t)}




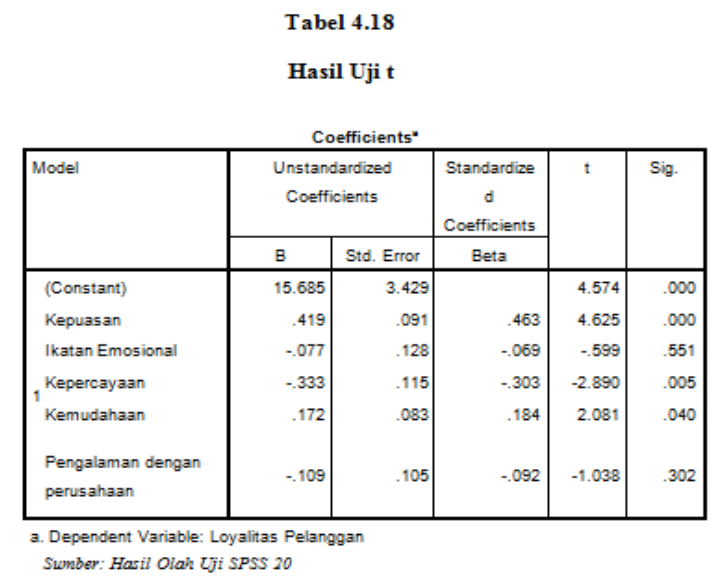

Dari tabel 4.18 dapat diketahui nilai $t_{\text {hitung }}$ dari masing-masing variabel. Selanjutnya, maka mencari nilai $t_{\text {tabel}}$, digunakan rumus sebagai berikut :

$$
\begin{aligned}
\mathrm{t}_{\text {tebel }} & =\alpha / 2 ; \mathrm{n}-\mathrm{k}-1 \\
& =005 / 2 ; 103-5-1 \\
& =0,025 ; 97
\end{aligned}
$$

Jika dilihat pada tabel distribusi $t$ dengan hasil perhitungan di atas, diketahui nilai $t_{\text {tabel }}$ adalah 1,98472 .

\section{Pembahasan Hasil Penelitian}

Dari latar belakang masalah yang telah dijelaskan pada bab 1. Maka penelitian ini bertujuan untuk mengetahui variabel kepuasan, ikatan emosional, kepercayaan, kemudahan dan pengalaman dengan perusahaan berpengaruh secara simultan maupun parsial terhadap loyalitas pelanggan di Naem 555 Cucian.

\section{Pembahasan Hasil Uji F}

Berdasarkan hasil analisis regresi dengan menggunakan model tersebut secara uji simultan (uji F) terdapat pengaruh yang signifikan antara variabel independen (kepuasan, ikatan emosional, kepercayaan, kemudahan, pengalaman dengan perusahaan) dengan variabel dependen (loyalitas pelanggan), hal ini dapat dilihat dari nilai $F_{\text {hitung }} 7,147$ dengan nilai signifikan sebesar $0,000<0,05$. Jika dibandingkan antara nilai $F_{\text {hitung }}$ dengan $F_{\text {tabel }}$ maka diperoleh hasil bahwa nilai $F_{\text {hitung }}$ sebesar 7,147 $>F_{\text {tabel }}$ 2,31 yang artinya terdapat pengaruh yang signifikan, maka dapat disimpulkan $\mathrm{H}_{\mathrm{O}}$ ditolak dan Ha diterima yang berarti hipotesis pertama terbukti kebenarannya yaitu variabel kepuasan, ikatan emosional, 
kepercayaan, kemudahan dan pengalaman dengan perusahaan berpengaruh secara simultan atau bersama-sama terhadap loyalitas pelanggan di Naem 555 Cucian.

\section{Pembahasan Hasil Uji t}

\section{Pengaruh Kepuasan Terhadap Loyalitas Pelanggan}

Hasil pengujian hipotesis secara parsial pada kepuasan $\left(\mathrm{X}_{1}\right)$, diperoleh nilai $\mathrm{t}_{\text {hitung }}$ sebesar 4,625 yang lebih besar dari $\mathrm{t}_{\text {tabel }}$ 1,98472 dan nilai signifikan 0,00 yang lebih kecil dari 0,05. Dari hasil tersebut dapat diketahui bahwa Ho ditolak dan Ha diterima, hal ini menunjukkan bahwa hipotesis yang menyatakan kepuasan berpengaruh terhadap loyalitas pelanggan diterima. Hasil penelitian ini sesuai dengan pendapat Hassan (2008:58) yang mendefinisikan bahwa kepuasan pelanggan merupakan fungsi dasar dari sejumlah value produk (kinerja) yang dipersepsikan oleh pelanggan disbanding dengan harapan sebelum menggunakan. Berdasarkan hasil jawaban kuesioner sebagian besar resonden setuju bahwa hasil akhir jasa (kinerja) yang diberikan Naem 555 Cucian dengan yang diharapkan belum maksimal, artinya semakin baik value (kinerja) yang diberikan seperti hasil pencucian pakaian yang bersih dan wangi, maka akan menigkatkan loyalitas pelanggan di Naem 555 Cucian. Hasil penelitian ini juga sesuai dengan penelitian yang dilakukan Suherti (2016) yang menyatakan bahwa kepuasan memiliki pengaruh yang signifikan terhadap loyalitas pelanggan.

\section{Pengaruh Ikatan Emosional Terhadap Loyalitas Pelanggan}

Hasil pengujian hipotesis secara parsial pada ikatan emosional $\left(\mathrm{X}_{2}\right)$, diperoleh nilai $t_{\text {hitung }}$ sebesar 0,599 yang lebih kecil dari tabel 1,98472 dan nilai signifikan 0,551 yang lebih besar dari 0,05. Dari hasil tersebut dapat diketahui bahwa Ho diterima dan Ha ditolak, hal ini menunjukkan bahwa hipotesis yang menyatakan ikatan emosional tidak berpengaruh terhadap loyalitas pelanggan diterima. Zikmund (2003:72) dalam Ifca Chendy (2015) mendefinisikan Ikatan yang tercipta dari sebuah merek ialah ketika konsumen merasakan ikatan yang kuat dengan konsumen yang lain menggunakan produk atau jasa yang sama. Hasil penelitian ini sesuai dengan penelitian yang dilakukan Sukoco, Badri Munir dan Reza Aditya Hartawan (2011) yang menyatakan bahwa ikatan emosional tidak memilki pengaruh yang signifikan terhadap loyalitas pelanggan. Adanya perbedaan dalam penelitian sebelumnya dapat dikarenakan merek dari suatu laundry tidak mempengaruhi pelanggan menggunakan jasa laundry tersebut. 


\section{Pengaruh Kepercayaan Terhadap Loyalitas Pelanggan}

Hasil pengujian hipotesis secara parsial pada kepercayaan $\left(\mathrm{X}_{3}\right)$, diperoleh nilai $t_{\text {hitung }}$ sebesar 2,890 yang lebih besar dari tabel 1,98472 dan nilai signifikan 0,005 yang lebih kecil dari 0,05. Dari hasil tersebut dapat diketahui bahwa Ho ditolak dan Ha diterima, hal ini menunjukkan bahwa hipotesis yang menyatakan kepercayaan berpengaruh terhadap loyalitas pelanggan diterima. Hasil penelitian ini sesuai dengan pendapat Abdurrahman (2015:434) yang mendefinisikan bahwa kepercayaan, yaitu keyakinan salah satu pihak yang dasarkan atas integritas pihak lain untuk memenuhi janjinya. Apabila perusahaan memenuhi komitmennya kepada pelanggan, kepercayaan akan tumbuh dan memperkuat kepercayaan pelanggan. Berdasarkan hasil jawaban kuesioner sebagian besar responden cukup setuju jika Naem 555 Cucian belum dapat memenuhi komitmennya kepada pelanggan seperti, menjaga keselamatan barang pelanggannya, artinya jika Naem 555 Cucian dapat menunjukan integritas serta komitmennya terhadap pelanggan, maka akan menumbuhkan kepercayaan pelanggan serta meningkatkan loyalitas pelanggan tersebut. Hasil penelitian ini juga sesuai dengan penelitian yang dilakukan oleh Sasha Dwi Harumi (2016) yang menyatakan bahwa kepercayaan memiliki pengaruh yang signifikan terhadap loyalitas pelanggan.

\section{Pengaruh Kemudahan Terhadap Loyalitas Pelanggan}

Hasil pengujian hipotesis secara parsial pada kemudahan $\left(\mathrm{X}_{4}\right)$, diperoleh nilai thitung sebesar 2,081 yang lebih besar dari $t_{\text {tabel }}$ 1,98472 dan nilai signifikan 0,040 yang lebih kecil dari 0,05. Dari hasil tersebut dapat diketahui bahwa Ho ditolak dan Ha diterima, hal ini menunjukkan bahwa hipotesis yang menyatakan kemudahan berpengaruh terhadap loyalitas pelanggan diterima. Hasil penelitian ini sesuai dengan pendapat Zikmund (2003:72) dalam Ifca Chendy (2015) yaitu, seorang konsumen akan merasa nyaman jika dalam melakukan pembelian dia mendapatkan kemudahan. Berdasarkan hasil kuesioner sebagian besar responden merasa setuju bahwa masih adanya kendala dalam melakukan transaksi, seperti fasilitas antar jemput pakaian, artinya beberapa fasilitas yang diberikan untuk memudahkan pelanggannya dalam melakukan transaksi dapat mempengaruhi loyalitas pelanggan di Naem 555 Cucian. Hasil penelitian ini juga sesuai dengan penelitian yang dilakukan Chendy Ifca (2015) yang menyatakan bahwa variabel kemudahan memiliki pengaruh yang signifikan terhadap loyalitas pelanggan.

Pengaruh Pengalaman Dengan Perusahaan Terhadap Loyalitas Pelanggan. 
Hasil pengujian hipotesis secara parsial pada ikatan emosional $\left(\mathrm{X}_{2}\right)$, diperoleh nilai $t_{\text {hitung }}$ sebesar 1,038 yang lebih kecil dari tabel 1,98472 dan nilai signifikan 0,302 yang lebih besar dari 0,05. Dari hasil tersebut dapat diketahui bahwa Ho diterima dan Ha ditolak, hal ini menunjukkan bahwa hipotesis yang menyatakan pengalaman dengan perusahaan tidak berpengaruh terhadap loyalitas pelanggan diterima. Frow and Payne (2007) dalam Dessy dan Yessy (2014) mengartikan customer experience atau pengalaman dengan perusahaan (history with company) adalah interprestasi seseorang konsumen terhadap interaksi total konsumen tersebut dengan sebuah merek. Hasil penelitian ini sesuai dengan penelitian yang dilakukan Sukoco, Badri Munir dan Reza Aditya Hartawan (2011) yang menyatakan bahwa pengalaman dengan perusahaan tidak memilki pengaruh yang signifikan terhadap loyalitas pelanggan. Adanya perbedaan dalam penelitian sebelumnya dapat dikarenakan merek dari suatu laundry tidak mempengaruhi pelanggan menggunakan jasa laundry tersebut.

Variabel Dominan Diantara Variabel Kepuasan, Ikatan Emosional, Kepercayaan, Kemudahan dan Penagalam Dengan Perusahaan

Dari hasil pengujian variabel independen yang terdiri dari kepuasan, ikatan emosional, kepercayaan, kemudahan, dan pengalaman dengan perusahaan yang mempunyai pengaruh paling dominan terhadap loyalitas pelanggan, yaitu variabel kepuasan. Hal itu dapat dilihat dari hasil uji thitung yaitu sebesar 4.652 dengan tingkat signifikan 0,000. Hasil penelitian ini sesuai dengan penelitian yang dilakukan Ifca Chendy (2015) yang menyatakan bahwa variabel kepuasan memiliki pengaruh yang paling dominan terhadap loyalitas pelanggan.

\section{PENUTUP}

\section{Kesimpulan}

Dari hasil analisis yang dilakukan mengenai pengaruh kepuasan, ikatan emosional, kepercayaan, kemudahan, pengalaman dengan perusahaan terhadap loyalitas pelanggan di Naem 555 Cucian, maka dapat ditarik kesimpulan sebagai berikut:

Berdasarkan hasil penelitianpengaruh secara simultan 
Berdasarkan hasil penelitian didapatkan hasil bahwa variabel kepuasan ikatan emosional. kepercayaan, kemudahan, pengalaman dengan perusahaan memiliki pengaruh simultan terhadap loyalitas pelanggan di Naem 555 Cucian.

Berdasarkan hasil penelitian pengaruh secara parsial

1. Berdasarkan hasil penelitian didapatkan hasil bahwa variabel kepuasan berpengaruh secara parsial terhadap loyalitas pelanggan di Naem 555 Cucian.

2. Berdasarkan hasil penelitian didapatkan hasil bahwa variabel ikatan emosional tidak berpengaruh secara parsial terhadap loyalitas pelanggan di Naem 555 Cucian.

3. Berdasarkan hasil penelitian didapatkan hasil bahwa variabel kepercayaan berpengaruh secara parsial terhadap loyalitas pelanggan di Naem 555 Cucian.

4. Berdasarkan hasil penelitian didapatkan hasil bahwa variabel kemudahan berpengaruh secara parsial terhadap loyalitas pelanggan di Naem 555 Cucian.

5. Berdasarkan hasil penelitian didapatkan hasil bahwa variabel pengalaman dengan perusahaan tidak berpengaruh secara parsial terhadap loyalitas pelanggan di Naem 555 Cucian.

Berdasarkan hasil pengujian variabel independen yang terdiri dari kepuasan, ikatan emosional, kepercayaan, kemudahan dan pengalaman dengan perusahaan didapatkan hasil bahwa variabel kepuasan memilki pengaruh paling dominan terhadap loyalitas pelanggan

\section{Saran}

Berdasarkan hasil penelitian dan kesimpulan di atas, maka peneliti mengajukan beberapa saran sebagai berikut:

\section{Kepuasan}

Dari hasil kesimpulan di atas, diketahui bahwa variabel kepuasan memiliki pengaruh yang signifikan terhadap loyalitas pelanggan. Dalam menangani keluhan atau yang dialami pelanggan sudah cukup baik, seperti memberikan sejumlah ganti rugi kepada pelanggan. Namun, sebaiknya karyawan lebih cepat dan tanggap dalam menangani keluhan tersebut, agar pelanggan memilki kepastian terhadap penaganan yang dilakukan.

Ikatan Emosional 
Dari hasil kesimpulan di atas, diketahui variabel ikatan emosional tidak terbukti memilki pengaruh yang signifikan terhadap loyalitas pelanggan, jadi meningkatkan variabel tersebut pun tidak akan berpengaruh terhadap loyalitas pelanggan di Naem 555 .

Kepercayaan

Dari hasil kesimpulan di atas, diketahui bahwa variabel kepercayaan memiliki pengaruh yang signifikan terhadap loyalitas pelanggan. Oleh karena itu, untuk meningkatkan kepercayaan pelanggannya, Naem 555 harus mampu memberikan keselematan terhadap barang pelanggannya, seperti pemberian nomor kode baju guna memudahkan untuk membedakan baju pelanggan agar tidak tertukar dan hilang. Serta melakukan pengawasan yang ketat dan teliti dalam proses pencucian hingga hasil akhir yang diharapkan pelanggan.

Kemudahan

Dari hasil kesimpulan di atas, diketahui bahwa variabel kemudahan memilki pengaruh yang signifikan terhadap loyalitas pelanggan. Beberapa fasilitas yang diberikan, seperti layanan antar jemput pakaian sudah cukup baik. Namun, sebaiknya karyawan lebih cepat merespon dan lebih mudah saat dihubungi saat adanya permintaan antar jemput pakaian.

Pengalaman Dengan Perusahaan

Dari kesimpulan di atas, diketahui bahwa variabel pengalaman perusahaan tidak memilki pengaruh yang signifikan terhadap loyalitas pelanggan, jadi meningkatkan variabel tersebut pun tidak akan berpengaruh terhadap loyalitas pelanggan di Naem 555 .

Bagi peneliti selanjutnya

Diharapkan hasil penelitian ini dapat menjadi referensi oleh penulis lain dalam penelitian mengenai hubungan antara variabel kepuasan, ikatan emosional, kepercayaan, pengalaman dengan perusahaan terhadap loyalitas pelanggan, tetapi dengan diketahuinya ada sebesar $73,1 \%$ pengaruh variabel bebas lain yang tidak diteliti dalam penelitian ini, maka disarankan untuk menambah variabel bebas lain yang tidak diteliti dalam penelitian ini, seperti variabel kualitas pelayanan.

\section{DAFTAR PUSTAKA}

Abdurrahman, Nana Herdiana. 2015. Manajemen Strategi Pemasaran. Pustaka Setia. Bandung 
Alfarsha, Rendy. 2018. Pengaruh Kualitas Pelayanan Terhadap Loyalitas Pelanggan Topklin Laundry. Skripsi. Universitas Katolik Parahyangan. Bandung

Arifin, Johar. 2017. SPSS 24 Untuk Penelitian dan Skripsi. PT Elex Media Komputindo. Jakarta

Asmarani, Bunga Puji. 2015. Pengaruh Kualitas Pelayanan, Kepercayaan, dan Kepuasan Terhadap Loyalitas . Studi Pada Konsumen Bus Harapan Jaya Tulungagung. Skripsi. Universitas Nusantara PGRI Kediri

Gennie, Articia Triza. 2019. Faktor-Faktor Yang Mempengaruhi Loyalitas Pelanggan Di Hotel Travelodge Batam. JOM FISIP. 6(1). 1-13

Ghozali, Imam. 2013. Aplikasi Analisis Multivariete dengan Program IBM SPSS 21. Universitas Diponegoro. Semarang.

2016. Aplikasi Analisis Multivariete dengan Program IBM SPSS 21. Universitas Diponegoro. Semarang.

Griffin, Jill. 2005. Customer Loyalty. Menambahkan dan Mempertahankan Kesetiaan Pelanggan. (Dwi Kartini Yahya, Penerjemah). Jakarta Erlangga.

Hardiawan, Anandya Cahya. 2013. Pengaruh Kepercayaan, Kemudahan dan Kualitas Informasi Terhadap Keputusan Pembelian secara Online (Studi Pada Pengguna Situs Jual Beli Online tokoBagus.com). Skripsi. Fakultas Ekonomika dan Bisnis Universitas Diponegoro. Semarang.

Harianto, Rudy Pudjut. 2017. Panduan Praktis SPSS untuk Penelitian. Heart and Soul Media Aksara. Balikpapan

Harumi, Sasha Dwi. 2016. Pengaruh Kepercayaan dan Kepuasan Pelanggan Terhadap Loyalitas Pelanggan di Perusahaan Seiko Laundry Medan. Analitika. 8(2) : 115-128

Hassan, Ali. 2008. Marketing. Edisi Pertama. Cetakan Petama. PT Buku Kia. Jakarta . 2014. Marketing dan Kasus-Kasus Pilihan. CAPS. Yogyakarta

Ifca, Chendy. 2015. Faktor-Faktor Yang Mempengaruhi Loyalitas Pelanggan Garudamiles Pada Maskapai Penerbangan Garuda indonesia Airways Di Pekanbaru. Jom FISIP. 2(1): 1-9.

Indriya, Dwi Ratna Dan Oetomo, Hening Widi. 2008. Hubungan Kinerja Produk, Persepsi Nilai, Ikatan Emosional, Reputasi Merek Dan Loyalitas Pelanggan. Skripsi. Sekolah Tinggi Ilmu Ekonomi Indonesia (STIESIA). Surabaya.

Jasfar, Farida. 2009. Manajemen Jasa, Pendekatan Terpadu. Jakarta : Ghalia Indonesia.

Kertajaya, Hermawan. 2007. Hermawan Kertajaya on Marketing. Edisi Soft Cover Mizan Media Utama. Bandung.

Kotler, Philip dan Kevin Lane Keller. 2009. Manajemen Pemasaran. Edisi 13 Jilid Dua. Jakarta Erlangga.

Mowen, Jhon dan Michael Minor. 2002. Perilaku Konsumen. Erlangga. Jakarta: Erlangga

Priyatno, Duwi. 2012. Belajar Olah Data Statistik Dengan SPSS. Andi. Yogyakarta.

Sangadji, Etta Mamang, dan Sopiah. 2013. Perilaku Konsumen: Pendekatan Praktis Disertai Himpunan Jurnal Penelitian. Andi Offset. Yogyakarta

Sugiyono, 2015. Metode Penelitian Kombinasi (Mixed Methods). Bandung. Peneliti Alfabeta.

2016. Metode Penelitian Kuantitatif, Kualitatif, Dan R\&D. Cetakan Keduapuluh Tiga. Alfabeta. Bandung.

Suherti. 2016. Pengaruh Kepuasan Terhadap Loyalitas Konsumen Laundry Kiloan di Dramaga Bogor. Skripsi. Fakultas Ekologi Manusia Institut Pertanian Bogor. Bogor. 
Sujarweni, V. Wiratna. 2014. Metodelogi Penelitian Lengkap, Praktis dan Mudah dipahami. PT Pustaka Baru Press. Yogyakarta.

Sukoco, Badri Munir dan Reza Aditya Hartawan. 2011. Pengaruh Pengalamn dan Keterikatan Emosional Pada Merek Terhadap Loyalitas Konsumen. Jurnal Manajemen Teori dan Terapan. 4(3) : 1-11.

Tjiptono, Fandy. 2008. Strategi Pemasaran. Edisi Ketiga. Andi Offset. Yogyakarta. . 2014. Pemasaran Jasa : Prinsip, Penerapan, dan Penelitian. Andi Offset. Yogyakarta 2015. Strategi Pemasaran. Edisi Keempat. Andi Offset. Yogyakarta.

Umar, Husein. 2013. Metode Penelitian untuk Skripsi dan Tesis. Rajawali. Jakarta.

Wulansari, Dessy dan Yessy Artanti. 2014. Pengaruh Pemasaran Berdasarkan Pengalaman, Pemasaran Emosional Terhadap Loyalitas Pelanggan. Jurnal Ilmu Manajemen. 2(4). $1770-1782$. 